\title{
THE DOMINANT TYPE OF PLANKTONS CONSUMED BY CLIMBING PERCH LARVAE (ANABAS TESTUDINEUS BLOCH) IN DANAU BANGKAU
}

\author{
RUKMINI \\ Faculty of Fisheries and Marine, Lambung Mangkurat University, Indonesia
}

\begin{abstract}
This research aimed to analyze dominant type of plankton which is consumed by Climbing Perch (Anabas testudineus) larvae in Danau Bangkau waters of South Kalimantan, Indonesia. The field observations were done by randomly purposive sampling. The results showed that dominant type of plankton eaten by climbing perch larvae namely Coconeis sp, Mougeotia sp, and Mougeotia sp (age 3 to 11 days), Coconeis sp, Brachionus sp, and Keratella sp (age of 11 to 15 days), Navicula sp, Diatoma sp, Brachionus sp, and Keratella sp (age of 15-19 days), Navicula sp, Brachionus sp, and Keratella sp (age of 19 to 23 days), Brachionus sp. and Keratella sp (age of 23 to 27 days), and Navicula sp, Brachionus sp, and Keratella sp (age of 27 to 31 days).
\end{abstract}

Keyword : plankton, climbing perch, Danau Bangkau

\section{INTRODUCTION}

Seeding efforts are alternative solutions to overcome the gap between supply and demand for seed. Even so, business continuity is limited by the survival rate of climbing perch larvae (Anabas testudineus Bloch, the local name in South Kalimantan "papuyu") is very low (Marlida, 2001). This is caused by the larval period is a critical period in the life cycle of fish. These conditions relate to the ability of larvae in the natural food form plankton received from outside at the time of transition and during the endogenous feeding to exogenous feeding. This transition is related to the ability of larvae to consume plankton and plankton conformity with the mouth opening size (Kamler, 1992). Natural food in the form of plankton larval phase that must be given in accordance with the size of the larval mouth opening, thus greatly affecting larval survival.

However, information about the type of plankton consumed by climbing perch larval in relation to plankton abundance in the waters has not been investigated so that there is no information. Climbing perch research conducted by several researchers only leads to the enlargement of business as reported by

Correspondence Author: Rukmini. Faculty of Fishery and Marine, Lambung Mangkurat University.

Email: rukmini@yahoo.com

Journal of Wetlands Environmental Management

Vol 6, No 1 (2018) 1 - 5

http://dx.doi.org/10.20527/jwem.v5i2.108
Robianti (2006) dan Morioka, S. (2009).

Climbing perch including fish th at is easy to reproduce by natural or artificial, but very high mortality of larvae that require more intensive study to find the development of mouth openings size and types of plankton are consumed by climbing perch larvae. The lack of information about the development of mouth openings size and types of plankton are consumed by climbing perch larvae, resulting the survival of climbing perch larvae still low so that fish farming is still lagging behind compared to other fish species.

\section{MATERIALS AND METHODS}

\section{Study Site}

Research was carried out in Danau Bangkau, Water Quality Laboratory of Faculty of Fisheries and Marine UNLAM Banjarbaru, and Balai Budidaya Ikan Air Tawar Mandiangin South Kalimantan.

\section{Sampling Procedures}

Gastrointestinal Uptake and Observations of Climbing Perch Larvae

(1) The larvae were sampled from 10 climbing perch of 3 days after the eggs hatch, and next 3 days interval for 31 days. (2) Samples of larvae dissected stomach and digestive tract removed, inserted into the sample bottle and given a $4 \%$ formalin 
preservative. (3) Observation was made to identify types of plankton in the stomach of larvae by using an electric microscope.

\section{Plankton Sampling}

Plankton sampling conducted following stages: (1) A total of $40 \mathrm{~L}$ water sampled from two different points. (2) Water samples filtered by plankton net that has been given a sample bottle at the bottom. (3) Add 4\% formalin solution on samples that have been there in a bottle.

\section{Data Analysis}

\section{Digestive tract of Climbing Perch Larvae}

Identification of typical plankton species that consumed by climbing perch larvae is done using occurrence frequency method. The frequency method was carried out by recording occurrence of each plankton that found in each stomach contents, as well as a totally empty channel. Each of plankton contained in the stomach that contains a number expressed in percent of all gastric larvae studied, but does not cover the stomach that does not contain. With this method obtained different types of plankton are consumed, but does not show the quantity or amount of plankton consumed and does not take into account the digested plankton. The method of frequency occurrence obtained by using the formula Effendie (1997):

$$
O i=\frac{F k}{\ln } \times 100 \%
$$

$\mathrm{Oi}=$ percentage frequency of the presence of one type of feed $(\%)$

$\mathrm{Fk}=$ frequency of the presence of one type of feed

$\ln =$ Number of fish larvae containing gastric

\section{Plankton Abundance}

The abundance of plankton calculated with the method of Hardy (1970) in Hisbi (1989), namely by the formula:

$$
N=\frac{n}{m} \times \frac{s}{a} \times \frac{1}{v}
$$

where:

$\mathrm{N}=$ Number of individuals per liter (or individual cells $\mathrm{L}^{-1}$ )

$\mathrm{n}=$ Number of individuals who are found (or individual cells)

$\mathrm{m}=$ number of drops of samples examined

$\mathrm{s}=$ volume of the preserved sample $(\mathrm{mL})$

$\mathrm{a}=$ volume of each drop of sample $(\mathrm{mL})$

$\mathrm{v}=$ volume of water filtered $(\mathrm{L})$

The measurements results of percentage frequency of the plankton species presence in the digestive tract of climbing perch larvae and plankton abundance in the waters Danau Bangkau subsequently tabulated. Interpretation of the results of the tabulation is poured into the form of tables and graphs.

\section{RESULTS}

\section{Gastrointestinal Analysis of Climbing Perch Larvae}

Based on the percentage frequency of the presence of plankton in the digestive tract, the predominant type of plankton eaten by climbing perch larvae namely: 3 to 7 day old larvae consumed Coconeis sp (15-70 $\mu \mathrm{m}$ length, volume 10-37 $\mu \mathrm{m}$ ) and Mougeotia sp (diameter 27-30 $\mu \mathrm{m}$ ), 7 to 11 day old larvae consumed Coconeis sp (15-70 $\mu \mathrm{m}$ length, 10$37 \mu \mathrm{m}$ volume) and Mougeotia sp (27-30 $\mu \mathrm{m}$ diameter). 11 to 15 days old larvae consumes Coconeis sp (15-70 $\mu \mathrm{m}$ length, 10-37 $\mu \mathrm{m}$ volume), Brachionus sp (length $105 \mu \mathrm{m}$ ) and Keratella sp (length $100 \mu \mathrm{m}), 15$ to 19 days old larvae consumed Navicula sp (36-60 $\mu \mathrm{m}$, 5-10 $\mu \mathrm{m}$ volume), Diatoma sp (40-110 $\mu \mathrm{m})$, Brachionus sp (length $105 \mu \mathrm{m}$ ), and Keratella sp (length $100 \mu \mathrm{m}), 19$ to 23 days old larvae consumed Navicula sp (36-60 $\mu \mathrm{m}, 5-10 \mu \mathrm{m}$ volume), Brachionus sp (length $105 \mu \mathrm{m}$ ), and Keratella sp (length $100 \mu \mathrm{m}$ ). 23 to 27 days old larvae consumed Brachionus sp (length $105 \mu \mathrm{m}$ ) and Keratella sp (length $100 \mu \mathrm{m}$ ). 27 to 31 days old larvae consumed Navicula sp (36-60 $\mu \mathrm{m}, 5-10 \mu \mathrm{m}$ volume), Brachionus sp (length $105 \mu \mathrm{m}$ ), and Keratella sp (length of $100 \mu \mathrm{m})$. These results complied with the method suggested by Shirota (1996). 


\section{Types of Plankton Abundance in Danau Bangkau}

Of 12 types of plankton found, there were six dominant plankton species consumed by climbing perch larvae i.e. Mougeotia sp $\left(265.50 \pm 9.99\right.$ cells $\mathrm{L}^{-1}$; mean $\left.\pm \mathrm{SD}\right)$, Coconeis sp of $246.3 \pm 9.53$ cells $\mathrm{L}^{-1}$, Keratella sp $\left(174.3 \pm 13.58\right.$ cells $\left.\mathrm{L}^{-1}\right)$, Chlorococcum sp $\left(110.11 \pm 14.34\right.$ cells $\left.\mathrm{L}^{-1}\right)$, Brachionus sp $\left(98 \pm 1.77\right.$ cells $\left.\mathrm{L}^{-1}\right)$ and Navicula sp (47.44 \pm 7.16 cells $\left.\mathrm{L}^{-1}\right)$ as presented in Table 1. Figure 1 shows the age distribution (days) of climbing perch larvae corresponding to the plankton abundance in Danau Bangkau
Table 1. The mean \pm SD of plankton abundance in Danau Bangkau

\begin{tabular}{clc}
\hline No. & Types of Plankton & $\begin{array}{c}\text { Mean } \pm \text { SD of } \\
\text { Plankton Abundance } \\
(\text { cell L-1) }\end{array}$ \\
\hline 1. & Chlorella $\mathrm{sp}$ & $38.50 \pm 2.90$ \\
2. & Coconeis $\mathrm{sp}$ & $246.30 \pm 9.53$ \\
3. & Mougeotia $\mathrm{sp}$ & $265.50 \pm 9.99$ \\
4. & Chlorococcum $\mathrm{sp}$ & $110.11 \pm 14.34$ \\
5. & Spirogyra $\mathrm{sp}$ & $27.33 \pm 3.87$ \\
6. & Binuclera $\mathrm{sp}$ & $13.33 \pm 0.85$ \\
7. & Pediastrum $\mathrm{sp}$ & $11.11 \pm 0.86$ \\
8. & Nitzschia $\mathrm{sp}$ & $13.10 \pm 2.58$ \\
9. & Navicula $\mathrm{sp}$ & $47.44 \pm 7.16$ \\
10. & Diatoma $\mathrm{sp}$ & $38.80 \pm 6.53$ \\
11. & Brachionus $\mathrm{sp}$ & $98.00 \pm 1.77$ \\
12. & Keratella $\mathrm{sp}$ & $174.30 \pm 13.58$ \\
\hline
\end{tabular}

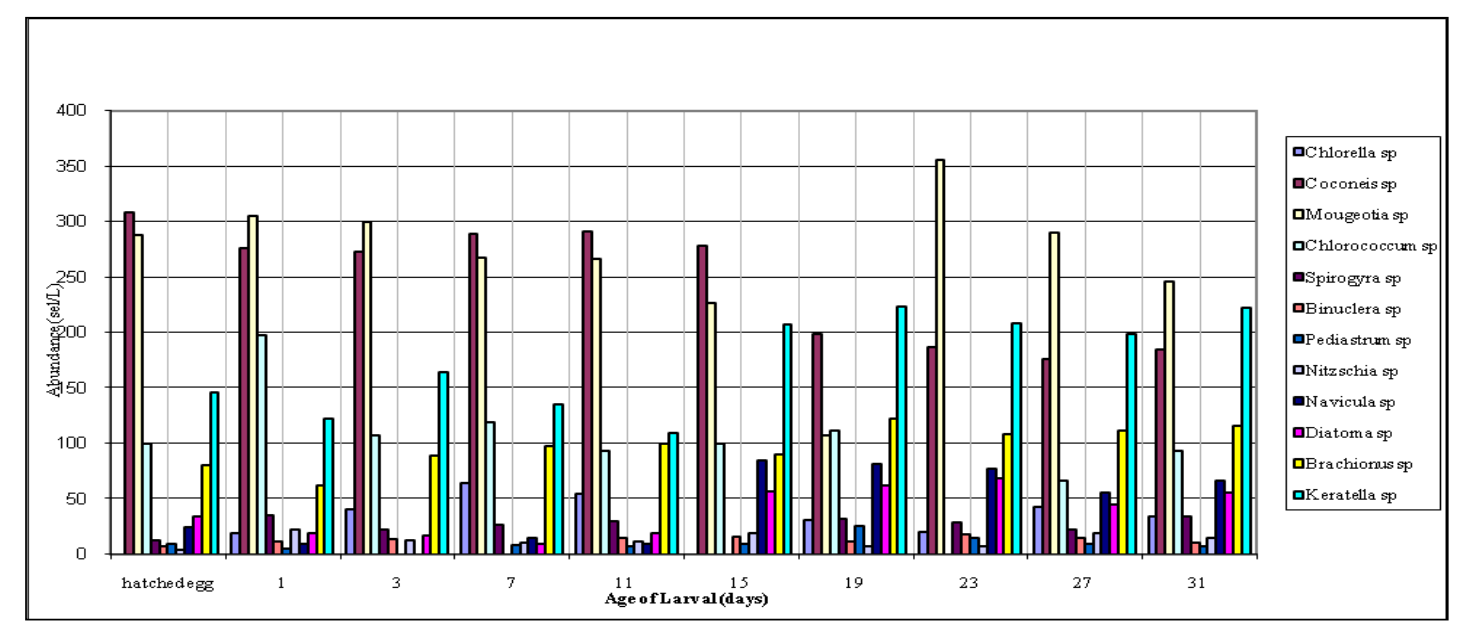

Figure 1. The age distribution (days) of climbing perch larvae corresponding to the plankton abundance in Danau Bangkau

\section{DISCUSSION}

\section{Gastrointestinal Analysis results of Climbing Perch Larvae}

Not all types of plankton in the aquatic habitat of Lake Bangkau consumed by climbing perch larvae from the age of 3 days until the age of 31 days, but only certain types of plankton are consumed. The types of plankton are consumed as a natural feed was changed in accordance with age of climbing perch larvae.

Climbing perch larvae consume plankton in the waters began at age 3 days, because yolk reserves (yolk) is almost absorbed out

Journal of Wetlands Environmental Management Vol 6, No 1 (2018) 1 - 5

http://dx.doi.org/10.20527/jwem.v5i2.108 and have started to open his mouth. According Waynarovich and Horvart (1980), larval fish with the yolk of the egg can live longer without food from outside. Along with the reduction in egg yolks, then the mouth opening and digestive tract is also growing. Feed fish larvae start looking outside at the time of yolk remaining about $20 \%$ to $30 \%$.

Plankton waters as a natural food that is consumed by climbing perch larvae has made changes to the abundance of plankton in the water, it can be seen from the percentage of plankton being consumed by climbing perch larvae. Plankton consumed by fish usually changes with the growth and morphology changes. 
On climbing perch larvae selectivity is also seen in the search for food, both in terms of species abundance and the number of available food resources in the waters. It can be seen from the plankton as feed consumed according to the number of climbing perch larvae abundance (density) plankton species found in waters as a live habitat for climbing perch larvae. Plankton abundance as a natural food is high in aquatic habitats where fish larvae and live according to will increase the chances of larvae ingested, so the amount consumed is a function of the density of the feed. According to Wootton (1994), factors that determine the selection of prey (natural food) is the availability of feed, which capture natural food will increase with increasing abundance of plankton, prey and predator characteristics, whether or not feed easily digestible and experience to feed predators. Feed consumed fish usually changes with the growth and morphology changes.

According to Nikolsky (1963), that during the growth process of fish, there is a change in the feed, with respect to changes in the structure of the fish. If the fish managed to get his life started with natural feed plankton according to the fish as an adult or growing larger fish feed that will change both in size and quality, if an adult fish will follow the pattern of its parent habits (Effendie 1978). According to Moss (1980) feed the fish often change substantially in accordance with increasing fish old.

\section{CONCLUSION}

Climbing perch larvae consumed plankton started from 3 days old since yolk reserves (yolk) is almost absorbed out and have started to open its mouth. The type of plankton consumed by larvae usually changes with the growth and morphology changes. Larvae selectivity is also seen in the search for food, both in terms of species abundance and the number of available food resources in the waters.

\section{ACKNOWLEDGMENTS}

My thanks go to Head of Balai Budidaya Ikan Air Tawar Mandiangin, Dean of the Faculty of Fisheries and Chairman of the Department/ Aquaculture Program Study of Fisheries and Marine Universitas Lambung Mangkurat Banjarbaru and all those who have helped this operation.

\section{REFERENCES}

Affandie RDS, Syafie MF, Rahardjo, Sulistiono. 2005. Fisiologi Ikan, Pencernaan dan Penyerapan Makanan. Departemen Manajemen Sumberdaya Perairan Fakultas Perikanan dan Ilmu Kelautan. Institut Pertanian Bogor.

Effendie MI. 1978. Biologi Perikanan (Bagian I Studi Natural History) Fakultas Perikanan. Institut Pertanian Bogor.

Effendie MI. 1997. Biologi Perikanan Bagian I Fakultas Perikanan. IPB, Bogor.

Hisbi Dj. 1989. Penelitian dan Monitoring Kualitas Air Sungai Barito yang Termasuk Kawasan Industri Perkayuan Jelapat Kotamadya Banjarmasin/ Kabupaten Barito Kuala Kalimantan Selatan. Bagian I Kerjasama KPSL Unlam dengan Pemda Tingkat I Kalimantan Selatan (Biro BKLH) Banjarmasin.

Kamler E. 1992. Early Life History of Fish. Chapman and Hall, London.

Marlida R. 2001 Kajian Fisiologi Pencernaan Dan Kelangsungan Hidup Larva Ikan Betok (Anabas testudineus Bloch) Yang Diberi Pakan Berbeda (Thesis). Program Pasca Sarjana Universitas Hasanuddin. Makassar.

Morioka S, Ito S, Kitamura S, Vongvichith B. 2009. Growth and Morphological Development of Laboratory-Reared Larval and Juvenile Climbing Perch Anabas testudineus. Journal of Ichthyology Research, 56: 162-171. 
Muhammad. 1987. Pengaruh Sumber Makanan Yang Berbeda Terhadap Pertumbuhan Ikan Betok (Anabas testudineus Bloch) yang di Pelihara Dalam Kolam (Skripsi). Fakultas Perikanan Universitas Lambung Mangkurat. Banjarbaru.

Moss B. 1980. Ecology of Freshwater. Blachwell Scientific Publication, Oxford, London, Exdinburgh dan Mebourne.

Nikolsky GV. 1963. The Ecology of Fishes. Translated from Rusian by I Birket. Academic Press. New York.

Normalinda. 2002. Pembesaran Ikan Betok (Anabas testudineus Bloch) dengan Padat Tebar yang Berbeda dalam Bak Plastik (Thesis). Fakultas Perikanan Universitas Lambung Mangkurat. Banjarbaru.
Robianti. 2006. Pengaruh Kadar Protein yang Berbeda terhadap Pertumbuhan Ikan Betok (Anabas testudineus Bloch) di Hapa (Thesis). Fakultas Perikanan Universitas Lambung Mangkurat. Banjarbaru.

Shirota A. 1996. The Plankton of South Vietnam. Overseas Technical Cooperation Agency Japan.

Waynarovich E, Hovart CC. 1980. The Artificial Propagation of Warm Water Finfishes a Manual for Extention, FAO Fish Tech 201.

Wotton RJ. 1994. Ecology of Teleost Fishes. Chapman and Hall. London. 